\title{
ADORA2B Gene
}

National Cancer Institute

\section{Source}

National Cancer Institute. ADORA2B Gene. NCI Thesaurus. Code C38613.

This gene plays a regulatory role in the enzymatic activity of adenylate cyclase and axon elongation. 